\title{
Clean Development Mechanism and Its Risk Management Policy in Urban Infrastructure Construction
}

\author{
Zhou Jun $^{1 *}$, Zhang Hongwei ${ }^{1}$ and Liu Yingjia ${ }^{2}$ \\ 1Central University of Finance and Economics, Management science and \\ engineering College, Beijing, China, 100081 \\ 2 Graduate School of Chinese Academy of Social Science, Department of \\ Investment Economics, Beijing, China, 102488 \\ cufezhouj@cufe.edu.cn
}

\begin{abstract}
Clean Development Mechanism (CDM) is a multi-win solution for the low-carbon development of urban infrastructure. It provides a low-cost plan and offering channels for technical transformation. Moreover, effective clean development strategy can certainly produce additional capital and technology benefits to meet the requirements of sustainability for urban infrastructure construction. This paper illustrates the clean development principles of urban infrastructure in a broader sense, and pay attention to the potential risk and controlling methodology of the CDM, which aims at promoting the formation and positive development of urban CMD system.
\end{abstract}

Keywords: Urban infrastructure, Construction, Clean Development, Risk Control

\section{Introduction}

Urban infrastructure plays an important role in ecological civilization. The implementation of clean development strategy will bring low-carbon economic and environmental benefits. A large amount of infrastructure with resource-saving, large capacity, low energy consumption and less pollution will take in multiple low-carbon advantage, which promotes the achievement of low-carbon eco-city. In modern urban infrastructure, the low-carbon characteristics are including:

(1) It can effectively reduce urban carbon emissions. For example, the per capita carbon emission of urban rail traffic was obviously lower than the traditional means, such as planes, cars and so on. Efficient and environmentally friendly infrastructure is an important part in reducing carbon dioxide emissions.

(2) It can clean environment and reduce pollution. The emission by traditional infrastructure has become one of the major sources of pollution in many cities. The entire process of modern urban infrastructure construction greatly reduces the emission of atmospheric pollutants by using electricity or other clean energy instead of traditional fossil fuel.

(3) It can achieve energy conservation and emission reduction. Modern urban infrastructure has a positive effect on the adjustment of emission structure and achieve energy-saving by lower energy consumption, high operation efficiency and advanced technology. The full use of renewable energy is conducive to the development of new energy and lowering the dependence on oil resources.

China's urban infrastructure is in a higher construction speed than ever before, along with high energy consumption and low efficiency, which indicates that there has a high potential in energy-saving. Low-carbon requirement in modern urban infrastructure implies the necessity and possibility of establishing the Clean Development Mechanism (CDM). 
Recently, both international and domestic conditions tend to mature. In the December of 1997, a legally binding called "Kyoto Protocol" was adopted. It has provided quantified indicators and specific obligations in the greenhouse gas emissions to each contracting party, which makes the market mechanism as a new path to solve the problem. In the November of 2009, Chinese government committed that China's unit GDP carbon dioxide emissions will decrease $40 \%$ to $45 \%$ before 2020 compared to which in 2005 . On the one hand, the announcement of emission reduction boosts pressure on all provinces; on the other hand it is bound to promote the prosperity of the domestic carbon trading market.

Therefore, it's necessary to study the clean development in infrastructure construction. In addition to taking effective measures to save energy and protect environment in the construction process, we need to establish standards and mechanisms to encourage qualified urban infrastructure projects entering domestic and international carbon trading market. The carbon trading based on construction project will have a profound impact. It will facilitate the achievement of low-carbon targets on city even national level and sustainability on construction project.

\section{Clean Development Principles of Urban Infrastructure Construction}

Cities need complete urban functions, which is mainly depends on infrastructure. Therefore, the urban infrastructure should insist sustainability in a clean development way. The clean development of urban infrastructure requires not only intrinsic motivation and mechanisms, but also taking advantage of external resources to achieve it faster and better.

Here we present "A + B" development model. A represents the energy conservation, low-carbon and clean in infrastructure's production and management. B represents a variety of flexible mechanism to achieve a low-carbon and clean development goals using by infrastructure, including cooperate with outside agencies. Therefore, in the "A + B" mode, the systemic integration technology should be adopted in the whole life of construction, operation and demolition to improve energy consumption structure and effectively develop various energy sources, which is to decrease carbon emission. In addition, an urban infrastructure project will meet with some insurmountable obstacles (for example, because of financial restriction, we have to use some kind of high-carbon material).To breakthrough those obstacles, we need to adopt some flexible mechanisms, such as CDM (Clean Development Mechanism), ET (emissions trading) and so on, to solve the environmental issues which are public goods by market methods and achieve the overall objective of the Clean Development in lower cost.

\subsection{Theoretical Basis}

Since there are development gaps in economic, science and technology, combining with other distinction such as human resources costs, the greenhouse gas marginal emission reduction costs diverse between countries. Through the Clean Development Mechanism (CDM), developed countries can cut down the greenhouse gas emissions costs and profit from trading in the CERs market; developing countries can get access to the economic benefits and advanced technology by selling CERs, which contributes to local sustainable development. Figure 1: 


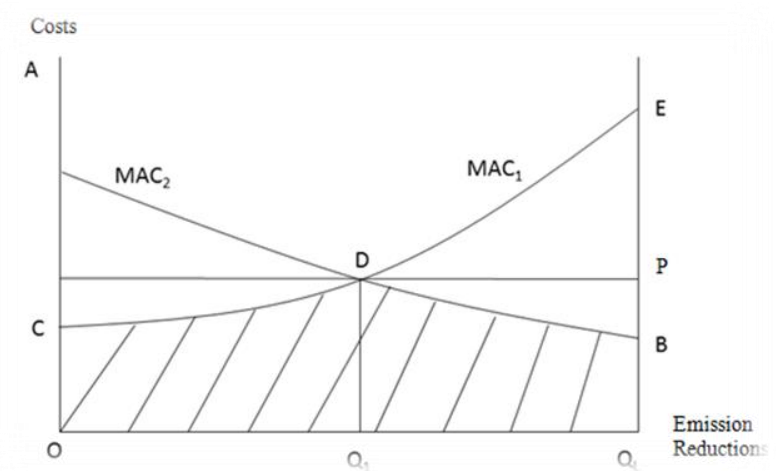

Figure 1. Marginal Abatement Cost Curve

$\mathrm{MAC}_{1}$ is the marginal emission reduction costs in developed countries, with the axes from left to right; $\mathrm{MAC}_{2}$ is the marginal emission reduction costs in developing countries, with the axes from right to left.

When developed countries reach the emission reductions $\mathrm{Q}_{\mathrm{L}}$ independently, the total cost is:

A refers to area.

$$
\mathrm{TC}_{1}=\int_{0}^{\mathrm{Q}_{\mathrm{L}}} \mathrm{MAC}_{1}(\mathrm{Q}) \mathrm{dQ}=\mathrm{A}_{\mathrm{COQ}_{1} \mathrm{Q}_{\mathrm{L}} \mathrm{E}}
$$

In the CDM case:

Assuming the price $\mathrm{P}$ paid by developed countries to developing countries; when it is less than $\mathrm{P}$, the reducing emissions in developed countries in is $\mathrm{Q}_{1}$ and the reduction in developing countries is $\mathrm{Q}_{2}$, in which

$$
\mathrm{Q}_{1}+\mathrm{Q}_{2}=\mathrm{Q}_{\mathrm{L}}
$$

We get the lowest total cost of emission reduction equilibrium, in which case, the total cost of emission reductions is:

$$
\mathrm{TC}_{2}=\int_{0}^{\mathrm{Q}_{1}} \mathrm{MAC}_{1}(\mathrm{Q}) \mathrm{dQ}+\int_{\mathrm{Q}_{1}}^{\mathrm{Q}_{\mathrm{L}}} \mathrm{MAC}_{2}\left(\mathrm{Q}_{\mathrm{L}}-\mathrm{Q}\right) \mathrm{dQ}=\mathrm{A}_{\mathrm{COQ}_{1} \mathrm{Q}_{\mathrm{L}} \mathrm{BD}}
$$

Since $\mathrm{MAC}_{2}<\mathrm{MAC}_{1}$, we get $\mathrm{TC}_{2}-\mathrm{TC}_{1}<0$.

Obviously, when the project adopts the CDM, the total cost of reducing emissions will decrease, with the amount equivalent to area DBE. Among which, the cost of reducing emissions in developed countries equals to the area DPE, the profit of developing countries equals to the area DPB. Thus, the CDM is a "kill three birds" method; it completes the emission reduction targets, achieves the lower emission reduction costs and makes partners achieve win-win.

\subsection{Project Cycle}

Internationally, from start to implement and until the final issuance of CERs, CDM projects need to go through eight main stages, namely: project identification, project design, state approval, project validation, project registration, project implementation, monitoring and reporting, the verification and certification of the emission reduction, CERs issuance.

\subsection{Methodology}

CDM project has a long period with complex stakeholders, requiring a complete system methodology as a guide. International CDM methodology generally includes five aspects: determining the baseline scenario, additional evaluation and demonstration, 
project boundary confirmation, the project emission reductions calculations and project monitoring plan. These methods are fully suitable in urban infrastructure projects.

2.3.1. Confirmation of the Baseline Scenario: The identification of the baseline scenario is the core of the methodology. Only if the baseline is determined can projects have comparable objects and can calculate the corresponding reductions. Baseline refers to the greenhouse gas discharged by other most likely construction projects (i.e. the baseline project) which achieve the same service utility without the Clean Development Mechanism.

General procedure to identify the baseline scenario is as follows:

1. List all realistic, credible and possible alternative scenarios of the project activities. The cases which do not comply with the laws and regulations should be removed.

2. Exclude the alternative scenarios which have insurmountable technical and financial barriers. After exclusion, if there is only one alternative scenario left, it is the baseline scenario of the project. If there are several alternative scenes, then select the lowest emissions scenario as the baseline scenario based on conservative principles.

3. Select the appropriate financial indicators to imply investment and sensitivity analysis. According to the final result, the most economical scenario is the baseline scenario.

2.3.2. Evaluation and Demonstration of Addition: If the project emissions are less than that of baseline scenario, the project is additional. Results of addition demonstration are used to judge the eligibility of the project. The project is registered only when it has addition. Demonstration of addition is the other core of methodology application except for project baseline. There is a close causal relationship between them. Through screening, if the project activity itself is approved to be clean baseline, the project is not additional. If not, it is additional.

2.3.3. The Confirmation of Project Boundary: The project boundary covers the physical and geographical boundaries of the project activities. The purpose of the project boundary is to exact confirm the involved emission sources, avoiding missing the relevant emission sources and ensure the accuracy of the calculation of project emissions.

The sense of determining the project boundary is to prevent a "leakage". Leakage refers to the net change of man-made measurable greenhouse gases sources emissions which is outside the project boundary but could attribute to the project activity (Sterk, 2006) ${ }^{[1]}$. Project emissions resulting from leaks also need to be deducted from the baseline emissions.

2.3.4. Emissions Calculation: Emissions calculation must be applied to methodology included in the validated project file.

The basic steps include:

1. Calculating emissions under the baseline scenario;

2. Calculating emissions of project activities;

3. Project emission reduction $=$ emissions under the baseline scenario - project emissions;

4. Deducting leak.

In an open market, it is sometimes difficult to determine what kind of situation is more likely to occur, therefore, we need to make a policy judgment. According to the judgment, use the following formula to calculate project emissions and emission reductions:

Baseline $=$ level of project activities $\times$ greenhouse gas emission factor under the baseline scenario (4) 
Project emissions $=$ level of project activity $\times$ emission factors of greenhouse gases by project technology or fuel (5)

Project emission reductions $=$ baseline emissions - emissions reductions projects (6)

If multiple gas reduction benefits from the project, the above calculation should be carried out for each gas. After the project emission reductions being calculated, the results need to be adjusted according to uncertainties and leakage.

2.3.5. Project Monitoring: Project monitoring is an important part in project applying and implementation, which determines the success of the project and the benefits achievement of CERs. In the Project Design Document (PDD), appropriate monitoring program must be included to ensure calculation of projects emission reduction accurately, transparently and verifiably. Meanwhile, the methods applied in monitoring plan must be approved, and gained recognition by DOE.

\section{Risk Control Analysis of Clean Development Mechanism (CDM) Project}

Internationally, since the implementation of CDM, each region or country is actively exploring its application, summarizing the implementation experience and improving the system process. China has the maximum number of CDM projects and CERs registered, but encountered all sorts of problems in the developing. At present, China economic grows rapidly with a greatly improved strength, so the applications of project cannot be confined to obtain funds on the sale of CERs. We should concern more about achieving sustainable development through CDM, and get access to advanced technology, promoting the transfer of low-carbon economy and achieving cleaner production, which are the core purposes of the development of such projects.

\subsection{Project External Factors}

\subsubsection{Complicated Procedures and Rules}

In order to ensure the smooth implementation, both the project application and its methodology follow comprehensive and systemic regulations, and all items must be in strict accordance with the requirement. In general, the international recognition of a project from initial project identification to the final registration needs about 1 to 2 years. The complicated implementation procedures and rules hinder the development of the market.

Project owners should particularly pay attention to the two following items:

1. Project Design Document (PDD) is an important basis of qualification, application and subsequent verification of eligibility and the necessary approval of the emission reductions, so PPD must be clearly and completely writing. The specific requirements are showed in Table 1.

2. Only when projects have additionality can pass the Registration and Verification. The "additionally demonstration analysis and evaluation tool" having been approved, which is based on the project internal rate of return (IRR), assuming that the investors will choose highest IRR project to invest. Therefore, the owner need to prove that when the project under the baseline scenario, it is not the most profitable projects. But after the introduction of the Clean Development Mechanism, the acquired funds make it more competitive. 


\begin{tabular}{|c|c|c|}
\hline Item & Notes & $\begin{array}{l}\text { Possible problems and } \\
\text { solutions }\end{array}$ \\
\hline $\begin{array}{l}\text { PDD report } \\
\text { template }\end{array}$ & $\begin{array}{l}\text { Use the latest version issued by } \\
\text { EB. } \\
\text { Cannot add or alter content in the } \\
\text { PDD pattern }\end{array}$ & \\
\hline $\begin{array}{l}\text { Project } \\
\text { participants }\end{array}$ & $\begin{array}{l}\text { More intuitive understanding to } \\
\text { project participants: how to } \\
\text { allocate the parties or private } \\
\text { and/or public entity with decision } \\
\text { to the CERs }\end{array}$ & $\begin{array}{l}\text { Cut down or give } \\
\text { instructions if agencies } \\
\text { which do not belong to } \\
\text { the project participants } \\
\text { were filled in the PDD }\end{array}$ \\
\hline $\begin{array}{l}\text { Project activity } \\
\text { category }\end{array}$ & $\begin{array}{l}\text { Distinction: general CDM projects } \\
\text { and small scale CDM project }\end{array}$ & \\
\hline $\begin{array}{l}\text { Approved } \\
\text { methodology }\end{array}$ & $\begin{array}{l}\text { After collecting opinions and } \\
\text { suggestions, if approved } \\
\text { methodology needs modify, it } \\
\text { cannot be used during } \\
\text { modification. }\end{array}$ & $\begin{array}{l}\text { During the old version } \\
\text { altered and before the } \\
\text { new version released, } \\
\text { still use the old version. }\end{array}$ \\
\hline $\begin{array}{l}\text { Additionality } \\
\text { analysis }\end{array}$ & $\begin{array}{l}\text { Each approved methodology } \\
\text { should give the specific methods } \\
\text { of how to carry out additional } \\
\text { analysis. }\end{array}$ & $\begin{array}{l}\text { Additionality analysis is } \\
\text { not clear enough, not } \\
\text { complete or off-topic. } \\
\text { Make sure only pay } \\
\text { attention to the specific } \\
\text { circumstance of the } \\
\text { project and avoid } \\
\text { analyzing the irrelevant } \\
\text { problem. }\end{array}$ \\
\hline $\begin{array}{l}\text { Keep monitoring } \\
\text { data on file }\end{array}$ & $\begin{array}{l}\text { Monitoring data should be } \\
\text { archived } 2 \text { years after the } \\
\text { crediting period. }\end{array}$ & $\begin{array}{l}\text { Not provide archiving } \\
\text { monitoring data. }\end{array}$ \\
\hline Measure unit & Use $\mathrm{tCO}_{2 \mathrm{e}}$ with uniformity. & $\begin{array}{l}\text { In the same PDD } \\
\text { report, use both units: } \\
\mathrm{tCO}_{2} \text { and } \mathrm{tCO}_{2 \mathrm{e}} \text {. }\end{array}$ \\
\hline $\begin{array}{l}\text { Units and } \\
\text { formulas }\end{array}$ & Formula errors, dimension error & $\begin{array}{l}\text { Check the formula } \\
\text { carefully, and use the } \\
\text { international standard } \\
\text { unit }\end{array}$ \\
\hline $\begin{array}{l}\text { Language } \\
\text { expression }\end{array}$ & $\begin{array}{l}\text { Clear and accurate presentation, } \\
\text { without opposition; } \\
\text { The English version should use } \\
\text { specialized vocabulary; }\end{array}$ & $\begin{array}{l}\text { Translation is } \\
\text { ambiguous. }\end{array}$ \\
\hline
\end{tabular}

3.1.2. Complicated Methodology: Registered projects of urban infrastructure are few, mainly due to its complicated application methodology. It requires a lot of data by pubic investment; therefore, the incredibility and acquisition become cardinal obstacles. In addition, the methodology requires a lot of monitoring data, which need take many factors into account. Moreover, the calculation methods, particularly the choices of the emissions sources have a large influence in monitoring data.

Due to the issues of methodologies complexity and difficulty in application, companies should be familiar with the methodology, selecting the appropriate comprehensive baseline and designing meaningful survey tables to get access to reliable data sources.

3.1.3. International Policy Factors: "Kyoto Protocol" is the basis of CDM mechanism. However, the first commitment period expires in 2012. In the Climate Conference in Durban, South Africa, the second commitment period of the Kyoto Protocol is just kept in form, and its legal effect, emission reduction targets of each country and other issues have not determined yet. This buries foreshadowing for the uncertainty of future negotiations. However, the determination of global emissions is 
firm, the CDM and other commercial mechanisms have not been abandoned. Moreover, this set of transparent mechanisms is the only one in the UN framework, so no matter what vulnerabilities exist in methodologies, CDM has the necessity to exist even develop rapidly.

\subsection{Project Internal Factors:}

\subsubsection{Avoid "the Trap of Funding Temptation"}

In this section, we point out that the project can obtain the CDM funds just only when it is additional. Moreover, the more important additionality reflects in the environmental and social benefits by the developing countries' projects, such as the obtaining of advanced technology, the improvement of resource supply and living environment. The development of urban infrastructure projects should avoid getting into the "trap of funding temptation" (only focus on getting the funds and ignore other benefits), which requires learn advanced foreign technology actively, introduce advanced management experiences, strengthen enterprises' management awareness and achieve the sustainable development while seeking for funding ${ }^{[3]}$.

3.2.2. Technical Limitations: Regardless of political factors, the biggest obstacle of the CDM projects' developing is the technology. Technical constraints are mainly reflected in:

1. Methodology application is simple, mainly concentrating on new energy projects. How to use other methodologies to prove that other projects have additionality is a weak part.

2. Designating operation entity is unstable, which staff is relatively in small scale and low professional level.

3. Talent human resources are lacking. The prediction to the complexity of the application is insufficient.

Currently CDM technical reporting modes have two categories: one is the development team set up by the projects' owners, mainly applicable to some large enterprises. The other is the cooperation with the professional organization in relevant fields. By strengthening communication and cooperation, the delay can be reduced. In addition, good consultancies is more professional in composing PDD, understanding and application of methodologies, which is laying the foundation of successful registration.

3.2.3. National Policies: The government pushed a policy to require all enterprises and industries conduct energy saving and emission reduction, which increases the pressure of reduce emissions on each enterprise. Moreover, in a long term, China will eventually become a net buyer. So the CDM project should have all-round development, not just focus on a few key areas. At present, China is simultaneously establishing relevant laws and regulations, establishing and improving the domestic carbon trading markets and safeguarding the healthy development of carbon emissions trading.

\subsection{Project Management:}

The CDM project has a complex process, a large-scale, a wide covers, a long development cycle and requiring high technology, which are serious challenges to project management. Enterprise should use advanced methods to enhance the comprehensive management capabilities, establishing the efficient project management system and improving project risk control mechanism to ensure the smooth implementation.

3.3.1 Schedule Control System: Compared with the research and civil engineering projects, CDM project is more likely to be affected by external factors. When the 
execution falls behind schedule, this project cannot be effectively promoted by additional resources and other means. Strictly speaking, CDM project which requires high-tech skills and easily distorted by external factors is in high-risk. Accounting for the intermediary consultancy, labor and other aspects of relatively high costs, once the project fails registered at the first time, it may cause infinite expansion the cost in the further application and affect the overall incomes.

\subsubsection{Risk Prevention System}

Characteristics of the project cause uncertainty in the projects from initiation to the issuance of CERs. Here we use Risk Breakdown Structure (RBS) to comprehensively analyze the risks that may meet. On the basis of risk identification, we propose specific measures according to characteristics, the risk level and the control point for each kind of risk, which are showed in Table 2.

Table 2. Risk Control

\begin{tabular}{|c|c|c|c|c|c|c|c|}
\hline \multicolumn{3}{|c|}{ RBS risks } & Risk control point & Risk level & Control type & Avoidance measures & remarks \\
\hline \multirow[t]{5}{*}{$\begin{array}{l}\text { Extern } \\
\text { al risk }\end{array}$} & $\begin{array}{l}\text { Policy } \\
\text { Risk }\end{array}$ & $\begin{array}{l}\text { Internatio } \\
\text { nal } \\
\text { environme } \\
\text { ntal risk }\end{array}$ & $\begin{array}{l}\text { 1."Kyoto Protocol" } \\
\text { first commitment } \\
\text { period is due. } \\
2 \text { The trend of } \\
\text { international carbon } \\
\text { market. }\end{array}$ & Important & Pre-control & $\begin{array}{l}\text { Companies need to } \\
\text { pay attention to } \\
\text { international dynamic } \\
\text { changes and enhance } \\
\text { communication with } \\
\text { professional } \\
\text { organizations. }\end{array}$ & Irresistible \\
\hline & & $\begin{array}{l}\text { Domestic } \\
\text { policy risk }\end{array}$ & $\begin{array}{l}1 \text { Related policy. } \\
2 \text { Approval criteria. } \\
3 \text { Related policies } \\
\text { in provinces. }\end{array}$ & Important & Pre-control & $\begin{array}{l}\text { Acquire national } \\
\text { policies and approval } \\
\text { procedure, and } \\
\text { communicate with } \\
\text { consulting agencies }\end{array}$ & \\
\hline & $\begin{array}{l}\text { Registrati } \\
\text { on and } \\
\text { audit risk }\end{array}$ & $\begin{array}{l}\text { DNA } \\
\text { approval } \\
\text { risk }\end{array}$ & $\begin{array}{l}\text { National } \\
\text { Development and } \\
\text { Reform } \\
\text { Commission will } \\
\text { evaluate CDM } \\
\text { projects }\end{array}$ & Important & $\begin{array}{l}\text { In-process } \\
\text { control }\end{array}$ & $\begin{array}{l}1 \text { Satisfy national } \\
\text { approval criteria. } \\
\text { 2. Satisfy international } \\
\text { regulations. } \\
3 \text { Cooperate with } \\
\text { professional } \\
\text { consulting agencies. }\end{array}$ & $\begin{array}{l}\text { Do the } \\
\text { preparatio } \\
\mathrm{n} \text { well }\end{array}$ \\
\hline & & $\begin{array}{l}\text { DOE } \\
\text { approval } \\
\text { and } \\
\text { verificatio } \\
n \text { risk }\end{array}$ & $\begin{array}{l}1 \text { Review the } \\
\text { registration } \\
\text { documents of PDD. } \\
2 \text { verification } \\
\text { reports by DOE } \\
\text { have a great impact } \\
\text { on final CERs. }\end{array}$ & Important & $\begin{array}{l}\text { In-process } \\
\text { control }\end{array}$ & $\begin{array}{l}1 \text { Make sure PDD } \\
\text { writing } \\
\text { 2. Monitoring should } \\
\text { strictly follow the plan. } \\
3 \text { Select DOE with a } \\
\text { high degree of } \\
\text { credibility. }\end{array}$ & \\
\hline & & $\begin{array}{l}\text { EB } \\
\text { approval } \\
\text { risk }\end{array}$ & $\begin{array}{l}1 \text { Whether pass the } \\
\text { registering of CDM } \\
\text { projects; } \\
2 \text { Whether pass the } \\
\text { application of CERs } \\
\text { issue }\end{array}$ & Important & $\begin{array}{l}\text { In-process } \\
\text { control }\end{array}$ & $\begin{array}{l}1 \text { Learn points of EB } \\
\text { audit, methodology, } \\
\text { and regulation } \\
2 \text { Select DOE with a } \\
\text { high degree of } \\
\text { credibility }\end{array}$ & \\
\hline
\end{tabular}




\begin{tabular}{|c|c|c|c|c|c|c|c|}
\hline & $\begin{array}{l}\text { Market } \\
\text { Risk }\end{array}$ & $\begin{array}{l}\text { Foreign } \\
\text { exchange } \\
\text { rate risk }\end{array}$ & $\begin{array}{l}\text { There will be } \\
\text { foreign exchange } \\
\text { rate risk in } \\
\text { international } \\
\text { settlement. }\end{array}$ & Important & Pre-control & $\begin{array}{l}1 \text { Set favorable price. } \\
2 \text { Reverse the trade in } \\
\text { the futures market; } \\
3 \text { Select enterprises } \\
\text { with huge capitals and } \\
\text { good reputation to } \\
\text { cooperate. } \\
\text { Create an index and } \\
\text { select strong currency } \\
\text { as a settlement } \\
\text { currency. }\end{array}$ & $\begin{array}{l}\text { Do the } \\
\text { preparatio } \\
\text { n well }\end{array}$ \\
\hline $\begin{array}{l}\text { Intern } \\
\text { al risk }\end{array}$ & $\begin{array}{l}\text { Process } \\
\text { Risk }\end{array}$ & $\begin{array}{l}\text { Methodolo } \\
\text { gy risk }\end{array}$ & $\begin{array}{l}1 \text { Whether } \\
\text { methodology } \\
\text { passed the } \\
\text { approval of EB; } \\
2 \text { Whether } \\
\text { methodology is } \\
\text { suitable for the } \\
\text { project. }\end{array}$ & $\begin{array}{l}\text { Very } \\
\text { important }\end{array}$ & Pre-control & $\begin{array}{l}1 \text { Using a method } \\
\text { approved by EB. } \\
2 \text {. Cooperate with } \\
\text { professional } \\
\text { consulting agencies } \\
\text { and select appropriate } \\
\text { methodology. }\end{array}$ & $\begin{array}{l}\text { Cooperate } \\
\text { with } \\
\text { profession } \\
\text { al CDM } \\
\text { consultanc } \\
\text { y agencies }\end{array}$ \\
\hline
\end{tabular}

3 New methodology should be applied to EB risk unable to assess important the expected greenhouse gas emissions.

$\begin{array}{ll}\begin{array}{l}\text { Additionali } \\ \text { ty }\end{array} & \begin{array}{l}1 \text { The selection of } \\ \text { the tool in }\end{array} \\ \begin{array}{ll}\text { approval } \\ \text { risk }\end{array} & \begin{array}{l}\text { Vergument; } \\ \text { important }\end{array} \\ & 2 \text { The integrity of } \\ \text { the content in } & \\ & \text { argument; } \\ & 3 \text { The effectiveness } \\ \text { of the content of } \\ \text { argument. }\end{array}$

\begin{tabular}{|c|c|c|}
\hline $\begin{array}{l}\text { Monitoring } \\
\text { risk }\end{array}$ & $\begin{array}{l}1 \text { Monitoring } \\
\text { methodology }\end{array}$ & $\begin{array}{l}\text { Very } \\
\text { important }\end{array}$ \\
\hline
\end{tabular}
application. 2 Integrity and effectiveness of monitoring plan and report.

\begin{tabular}{lllll}
\hline $\begin{array}{l}\text { Result } \\
\text { risk }\end{array}$ & $\begin{array}{l}\text { CERs lack } \\
\text { risk }\end{array}$ & $\begin{array}{l}\text { A variety of } \\
\text { unpredictable risks }\end{array}$ & Important & Later control \\
& $\begin{array}{l}\text { Buyer } \\
\text { qualificati } \\
\text { on risk }\end{array}$ & $\begin{array}{l}\text { Carry out } \\
\text { background } \\
\text { surveys }\end{array}$ & Important & Pre-control \\
& & & & \\
\hline
\end{tabular}

Pre-control

1. Accuracy and rigor.

\section{Transparency}

3.Feasibility and broad applicability.

4. Repeatability.

5.Conservatism

6.Consistency;

1. Reflect the specific circumstances of the project to the utmost.

2. Reflect circumstances of sectors or regions. 3 Fewer systematic errors.

4 Lower uncertainty;

5 Acceptable cost;

6 Reasonable data.

1. Use the methods approved by EB.

2. Make a complete and effective monitoring plan. 3. Strictly enforce monitoring program.

$\begin{array}{ll}\text { 1.Set the } & \text { Do the } \\ \text { compensation method } & \text { preparatio } \\ \text { in the contract; } & \mathrm{n} \text { well } \\ 2 \text { Introduce a risk } & \\ \text { intermediary. } & \\ \text { Cooperate with } & \\ \text { international famous } & \\ \text { institutions }\end{array}$




\subsubsection{Cost Control System}

On the one hand, developing CDM projects can introduce advanced technology and promote technical reformation; on the other hand, it can bring real capital gains and realize the increase in corporate profits. According to the project development cycle, the costs of the CDM projects generally consist of three parts: Pre-project cost, project registration cost and later cost.

1. Pre-project cost primarily include identifying projects expense, the contract price of cooperating with consulting parties, the relevant documentation expenses, travel expenses and so on. At this stage, it's uncertain to determine whether the project is able to set up, so the early costs are in risk. The time enterprises entering the carbon market is a "double-edged sword". Prematurely entering is likely to lead to high trading cost due to the lack of relevant experience. However, lately entering is possible to miss well cooperate opportunities. Therefore, enterprises should take the macroeconomic policy and their own conditions into consideration, selecting the appropriate point to enter the market and control the pre-project costs.

2. Project registration cost. All projects need audit by designated operational entity (DOE) and registering by Validation Report of the Executive Board (EB), and only after registered by EB can it have an effect. Cost incurred at this stage constitutes the registration process costs, mainly including: designated operational entity (DOE) validation costs and EB registration fee. During the crediting period, project owners hand in certain administrative cost annually. Conversely, if the project fails to register, the part of registration fee which is more than $\$ 30,000$ will be refunded by EB.

3. The later cost. The later cost consists of administrative fees, certification fees and monitoring report fees. Among them, the fixed costs are administrative costs. The certification fee is to hiring a third-party designated operational entity (DOE) to certify after register.

Despite of the high potential emission reduction in urban infrastructure, only projects with sufficient economic attractiveness will likely to be chosen to develop. Considering trading costs, the projects which emission reductions are below $15000 \mathrm{tCO}_{2 \mathrm{e}}$ do not have market attractiveness. Therefore, CDM can help project in its finance to some degree, but it is better to do pre-budget and estimate target cost. If the input-output ratio of the project is too low, it is not necessary for the project owners to apply it due to the risk. If the input-output ratio is too high and additional funds can improve the income, it should according to the project plan to apply in advance.

\section{Conclusions}

At present, China has become the world biggest developing country in urban infrastructure construction. For instance, by December 31, 2010, 47 mainland cities are constructing or planning new urban rail transit lines, with a total planned mileage more than $10000 \mathrm{~km}$ and a total investment over one trillion Yuan, indicating that the urban infrastructure construction is in the peak. In this paper, reference for a mature CDM theory and method, we deeply analyze the clean development mechanism in urban infrastructure, focusing on clean development principles and risks, making feasibility recommendations and providing a useful reference for clean urban CDM. Although China's urban infrastructure construction has made great achievements, there still wide gaps in resource consumption, fully functioning and sustainable development between developed countries. As a result, China is bound to take the effective CDM. 


\section{Acknowledgements}

We would like to thank the experts and reviewers in infrastructure construction for their valuable advice. This research project (Grant No. 71372192) was supported by National Natural Science Foundation of China.

\section{References}

[1] S. Wittneben, "Enhancing the clean development mechanism through sectorial approaches: definitions, applications and ways forward", International Environmental Agreements: Politics, Law and Economics, vol. 6, (2006).

[2] National Climate Change Coordination Committee, Tsinghua University, China CDM project development guide. China Environmental Science Press, Beijing (2006), pp. 50-52.

[3] X. M. Wang, "Clean Development Mechanism (CDM) international cooperation research", Beijing University of Posts and Telecommunications Press, Beijing (2010), pp. 148-150.

[4] W. X. Wu, "Strategic concept of post-Kyoto carbon emission rights allocation", Nanjing University of Technology, vol. 2, (2010).

[5] S. J. Liu and Y. S. Zhang, "Global greenhouse gas emissions: theoretical framework and solutions", Economic Research, vol. 3, (2009).

[6] J. Y. Li and T. Bie, "Clean Development Mechanism and implementation of legal protection in China", China University of Geosciences (Social Science Edition), vol. 8, (2008).

[7] S. Zhou and H. Tong, "Uncertainty risk study of CDM project development", Ecological economy, vol. 9, (2010).

[8] Z. Q. Li, "CDM greenhouse gas emissions and the third-party certification", China Environmental Science Press, Beijing (2009), pp. 128-130.

[9] M. S. Duan and S. Zhou, "CDM Methodology Application Guide", China Environmental Science Press, Beijing (2009), pp. 117-120.

\section{Author}

Zhou Jun, he is an Associate Professor at Central University of Finance and Economics. He received his doctoral degree from Beijing Jiaotong University, China. His research and teaching areas include project management, BIM, sustainable construction and quality control. 
International Journal of Security and Its Applications

Vol.9, No.7 (2015) 